\title{
Efficiency enhancing or anti-competitive vertical restraints? Selective and exclusive car distribution in Europe
}

\author{
24 August 2007
}

Frank Verboven

Katholieke Universiteit Leuven and C.E.P.R.

Forthcoming book chapter in Cases in European Competition Policy: the Economic Analysis, edited by Bruce Lyons, forthcoming Cambridge University Press (2008)

\footnotetext{
Acknowledgements: The author would like to thank, without implicating, Bruce Lyons and Frank Wijckmans for very helpful comments. The author has written two independent policy reports for the European Commission, in preparation of the block exemption reform in 2002 (Regulation 1400/2002): one on documenting and interpreting international price differentials (with Hans Degryse) and one on defining the relevant product markets for cars. These and other reports are available for download at: http://ec.europa.eu/comm/competition/car_sector/distribution/
} 
1 INTRODUCTION.

2 DISTRIBUTION AGREEMENTS IN THE CAR MARKET ...........................................5

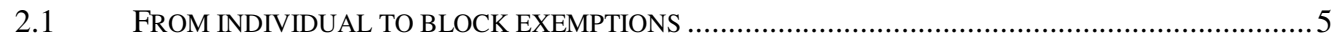

2.2 THE CAR DISTRIBUTION SYSTEM BETWEEN 1985 AND 2002 ............................................. 6

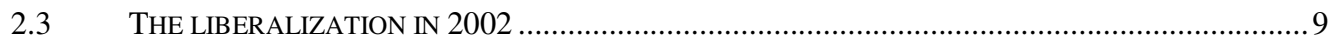

$2.4 \quad$ USE AND ENFORCEMENT OF THE BLOCK EXEMPTION ........................................................ 12

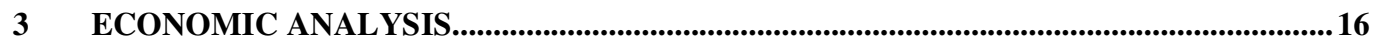

EFFICIENCIES FROM DISTRIBUTION AGREEMENTS.......................................................... 17

3.1.1 Mitigating double marginalization problems …...................................................... 17

3.1.2 Dealer services incentives and free-riding ........................................................... 18

3.1.3 Manufacturer investment incentives and free-riding .................................................... 20

3.2 LIMITED CROSS-BORDER TRADE AND INTERNATIONAL PRICE DIFFERENCES .......................20

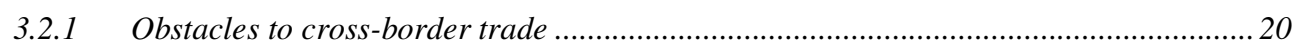

3.2.2 International price differences............................................................................. 22

3.3 LIMITED DOMESTIC TRADE AND SOFTENING INTERBRAND COMPETITION .......................... 23

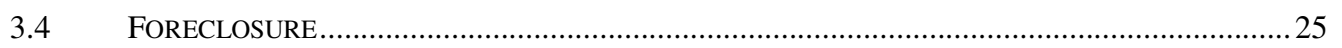

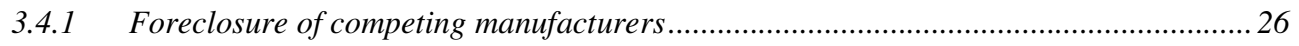

3.4.2 Foreclosure of spare part manufacturers .................................................................... 27

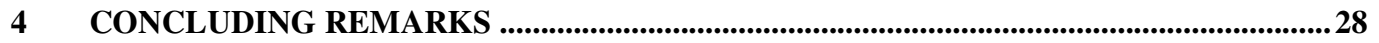

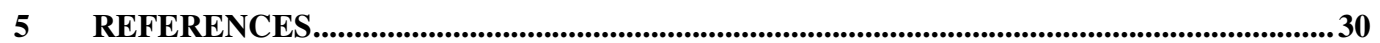




\section{Introduction}

Vertical agreements between the European car manufacturers and their dealers have existed since the emergence of the industry. They have been claimed to be necessary for an efficient distribution, though they also raise concerns about enhancing market power. One main vertical restraint has been selective distribution. This enables manufacturers to impose various criteria on their dealers, such as tying of sales and after-sales services, and to prohibit sales to independent resellers. A second main restraint has been exclusive distribution, through which manufacturers can assign an exclusive territory to their dealers. A third main restraint has been exclusive dealing (or the non-compete obligation), allowing manufacturers to prohibit dealers from selling multiple competing brands.

These restraints were initially allowed as individual exemptions under Article 81 of the EC Treaty. Since 1985 they became institutionalized as a block exemption, applicable to the whole car sector. The exemption was very formalistic on which types of agreements were acceptable, so that in practice a standardized distribution system emerged, with all manufacturers adopting essentially the same selective and exclusive distribution agreements. After minor revisions in 1995, more drastic reforms took place in 2002. The European Commission aimed to adopt a more economic approach and give the manufacturers more freedom of choice between alternative distribution forms (hence avoiding the "straitjacket effect"). At the same time, the Commission wanted to be stricter towards the manufacturers, because of a fear of "cumulative anticompetitive effects" if all manufacturers adopt the same or similar vertical restraints. As a result, the new block exemption in 2002 no longer allowed manufacturers to impose both selective and exclusive distribution to their dealers, but rather made them choose to adopt one or the other. Furthermore, the conditions for exclusive dealing arrangements (or non-compete obligations) became stricter to the manufacturers.

This chapter documents the recent history of the car distribution system in Europe to show the European Commission's evolving attitude towards vertical restraints. Vertical restraints have become increasingly based on competition economics. During the mid-eighties, when the first block exemption was installed, the Commission has 
mainly been preoccupied with restrictions to cross-border trade, to fulfill its goal of European integration. In more recent years, the Commission appears to have shifted its emphasis more towards the core competition policy concerns with vertical agreements, mainly the promotion of intrabrand competition (between dealers of the same brand) and to some extent also interbrand competition (between different manufacturers). We will argue that the Commission is finally focusing on the more relevant issues from a competition policy perspective, yet further improvements in economic analysis are strongly desirable. First, the policy objectives should become more transparent. Second, a deeper economic analysis is required regarding the recently adopted market share thresholds and regarding the various channels through which the vertical restraints may create efficiencies or anti-competitive effects. Recent empirical evidence suggests that the anti-competitive effects that were emphasized in the 2002 reforms (limited cross-border trade and domestic intrabrand competition) appear to be of less concern, suggesting that the stricter policy towards car producers may not have been warranted. However, before concluding that efficiency arguments in favor of the vertical restraints dominate, other possible anticompetitive effects (e.g. foreclosure of entry) need more careful empirical analysis in future work. Third, a stronger basis should be provided for the stricter policy towards distribution agreements in the car sector than towards distribution agreements in general, for which a parallel block exemption exists.

The outline of this chapter is as follows. In section 2 we describe the distribution system, how it has evolved and how it has been enforced. In section 3 we provide an economic analysis. We begin with a discussion of the various efficiencies that can be achieved by such agreements. We then turn to the possible anticompetitive effects, including the effects on cross-border trade, on intrabrand and interbrand competition given market structure, and on foreclosing new entry (e.g. by other foreign car manufacturers or spare parts producers). 


\section{Distribution agreements in the car market}

\subsection{From individual to block exemptions}

The vertical agreements between the European car manufacturers and their dealers were first subject to the national and subsequently to the European competition laws. Article 81(1) of the EC Treaty prohibits agreements that may affect trade between member states, and which may prevent, restrict or distort competition. Article 81(3) allows for exemptions, if there are benefits that outweigh the anticompetitive effects and if consumers receive a fair share of these benefits. In the early years, car manufacturers often submitted notifications to obtain individual exemptions for their own specific types of agreements. In 1965, to reduce the administrative burden in assessing similar agreements, the European Commission became authorized to grant block or group exemptions for certain categories of agreements falling under Article 81. Block exemption regulations essentially define a set of agreements and possibly market share thresholds for which there is a safe harbor, i.e. a presumption that the benefits from the agreement outweigh the anticompetitive effects. If the firm proposing the agreement has a market share above the threshold, the agreement is not necessarily illegal but an individual exemption needs to be obtained. ${ }^{1}$ In addition, block exemption regulations define a set of hardcore restrictions or black clauses, with the presumption that the benefits do no outweigh the costs regardless of the firm's market share.

A key individual exemption was the European Commission's 1974 BMW decision, granting BMW to possibility of combining both selective and exclusive distribution. ${ }^{2}$ As discussed by Wijckmans, Tuytschaever and Vanderelst (2006) this was a landmark case, as it laid the foundation for the future block exemptions for cars. ${ }^{3}$ The European Commission hoped that other manufacturers would adapt their distribution systems accordingly. In 1985, after a long process of consultations with interested parties, the first block exemption for agreements in the car sector was eventually introduced,

\footnotetext{
1 Since May $1^{\text {st }} 2004$, the exemption no longer needs to be requested and obtained. It applies automatically as long as the conditions in Art. 81(3) are fulfilled. This implies the parties may need to show proof ex post if the question arises (e.g. because of a procedure).

${ }^{2}$ Bayerische Motoren Werke AG (1975) OJ L29/1.
} 
Regulation 123/1985. ${ }^{4}$ This regulation applied to agreements covering both sales and after-sales services; agreements covering only one of both aspects did not fall under the exemption. It effectively installed a system that combined both selective and exclusive distribution, as well as the possibility to engage in exclusive dealing agreements. It also included some black clauses, such as resale price maintenance. The regulation was renewed for another seven years in 1995, as Regulation $1475 / 1995$, with only minor modifications to the previous system.

In 2002, a more drastic reform of the car distribution system was introduced, Regulation 1400/2002, with a one-year transition period for existing agreements and expiring in 2010. This block exemption followed a similar philosophy as the recently installed block exemption for distribution agreements in general, Regulation 2790/1999. ${ }^{5}$ Nevertheless, it was considerably stricter because of a concern with the "cumulative anticompetitive effects" of restrictive practices when almost all firms in the car market choose to adopt the same agreements. In essence, the new block exemption no longer allows the car manufacturers to combine both selective and exclusive distribution, and it forces exclusive dealing agreements to become less restrictive.

We now discuss the key properties of the distribution system in more detail. We begin with the period 1985-2002, and then the period since 2002. Finally, we discuss enforcement of the competition laws.

\subsection{The car distribution system between 1985 and 2002}

The first block exemption, Regulation 123/85, offered the possibility of both selective and exclusive distribution agreements, as well as exclusive dealing (non-compete obligation). Selective and exclusive distribution agreements have in common that they limit the number of authorized dealers and restrict their possibilities of resale. Table 1

\footnotetext{
${ }^{3}$ Wijckmans et al.'s contribution provides a very interesting analysis of the implications of the new regulation, complementary to this section.

${ }^{4}$ At the national level block exemptions already existed in some countries. For example, in the United Kingdom, the 1976 Restrictive Trade Practices Act provided a number of restrictions that were automatically exemption and did therefore not require registration. See the U.K. Competition Commission (2000).
} 
compares how these restrictions work under both contractual forms. Under selective distribution, the manufacturer can impose quantitative and qualitative criteria on its dealers. Quantitative criteria refer to the possibility to directly limit the total number of dealers in the country. Qualitative criteria are, for example, minimum standards of staff training, upfront advertising and marketing investments requirements, showrooms, demonstration cars, stock levels, performance of warranty works. Qualitative criteria also include the possibility to tie new car sales and after-sales repair and maintenance services, and to use the spare parts supplied by the manufacturer. Finally, sales targets (and the associated bonuses) and annual advertising obligations may be viewed as qualitative criteria in selective distribution. ${ }^{6}$ To protect the selective nature of the agreement, dealers are prohibited from selling to independent resellers. Hence, dealers are only allowed to sell to end-consumers, to intermediaries with a written authorization, or to other dealers within the manufacturer's distribution network.

Under exclusive distribution, the manufacturer can appoint a single dealer in a designated territory (e.g. a city or a municipality). To enforce exclusivity, the manufacturer can prohibit its dealers from engaging in active selling policies outside their territories, thus forcing them to concentrate their marketing and sales efforts within their own territory. This includes the location clause, i.e. the prohibition to set up secondary dealerships in other territories or abroad. It also includes the prohibition to advertise outside the own territory.

Table 1. Selective versus exclusive distribution

\begin{tabular}{lll}
\hline Distribution & \multicolumn{1}{c}{$\begin{array}{c}\text { Restrictions imposed on } \\
\text { authorized distributors }\end{array}$} & \multicolumn{1}{c}{ possibilities of resale } \\
Selectivity & $\begin{array}{l}\text { quantitative and qualitative } \\
\text { criteria }\end{array}$ & $\begin{array}{l}\text { no sales to independent } \\
\text { reseller }\end{array}$ \\
Exclusivity & geographic territory & no active selling policies in \\
& & other territory
\end{tabular}

\footnotetext{
${ }^{5}$ Verouden (2004) provides a comprehensive discussion of the emergence of this block exemption regulation, against the background of the historic enforcement of Article 81 in general, and the increased role of economic analysis.
} 
The block exemption regulation also allowed exclusive dealing agreements, or noncompete obligations, meaning that dealers can be prohibited from selling cars of competing brands. At that time, these restrictions (selective distribution, exclusive distribution, and exclusive dealing) were acceptable as block exemptions to Art. 81 without further investigation, regardless of the manufacturers' market share.

But the block exemption regulation also specified some black clauses, which are never acceptable (regardless of the market share). An important one is resale price maintenance (RPM) or vertical price fixing (though recommended retail prices or maximum prices fall under the block exemption). Another important black clause is the prohibition of passive selling to consumers outside the territory or outside the country (as long as these sales do not result from active selling policies). ${ }^{7}$

The block exemption was renewed in 1995, Regulation 1475/95. Despite a detailed investigation and consultation process, there were only some clarifications and minor relaxations of the restrictions to stimulate competition. ${ }^{8}$ Regarding selectivity, the condition was made explicit that manufacturers should not prevent end-consumers, or intermediaries with a written authorization, to purchase from any dealer they want (e.g. a named consumer in the UK can use an intermediary to buy a car in Belgium). Dealers could also more easily purchase their spare parts from other sources than the car manufacturers (still provided that these are of matching quality and are not used in warrantee works). Regarding exclusivity, general advertising campaigns outside the territory became allowed, though personalized targeted advertising remained prohibited to consumers outside the territory. Finally, regarding exclusive dealing, dealers obtained the right to sell multiple brands, but only provided that these would operate under separate legal entities, separate showrooms and separate management. In practice, this meant that dealers can realize only limited cost savings in selling multiple brands.

\footnotetext{
${ }^{6}$ There is some discussion that sales targets may be viewed as quantitative criteria, see Wijckmans, Tuytschaever and Vanderelst (2006). This discussion is especially relevant for the most recent block exemption, since the market share thresholds only apply to quantitative criteria, as discussed below.

${ }^{7}$ Dealers have the right not to sell to end-consumers, as long as this is not forced by the manufacturers in an agreement.
} 


\subsection{The liberalization in 2002}

In 2002, the European Commission introduced a more drastic reform of agreements in the car sector, Regulation 1400/2002. ${ }^{9}$ The new block exemption aimed to get rid of the rigid "straitjacket" model for car distribution, and offer greater flexibility on acceptable agreements. It was much in the spirit of the block exemption for distribution agreements in general, Regulation 2790/99, though it was considerably stricter on car manufacturers because of the fear of cumulative effects. The new block exemption still lists a number of black clauses that are not tolerated under any circumstances, notably RPM and the prohibition of passive selling outside the territory. There are several key differences that make the new system stricter on manufacturers than the system during 1985-2002.

First, manufacturers can no longer combine both selective and exclusive distribution. Hence, they have to opt for one or the other. In practice, most manufacturers (except Suzuki) have chosen to abandon exclusive distribution and adopt selective distribution. This means that they can impose certain objective qualitative or quantitative criteria to their dealers, including sales targets with some relaxations ${ }^{10}$ and a maximum total number of authorized dealers selling new cars. Selectivity also implies that authorized dealers are prohibited from selling cars to independent resellers. ${ }^{11}$ But because of the abandonment of exclusive distribution manufacturers can no longer prohibit their dealers to engage in active selling policies outside their territory (whether through opening secondary outlets in other territories or abroad, or through personalized advertising campaigns outside the own territory). ${ }^{12}$

\footnotetext{
${ }^{8}$ For more detailed comparisons between the 1985 and 1995 block exemption regulations, see the European Commission (2000) or the U.K. Competition Commission (2000).

9 These reforms were partly based on the Commission's own investigation, and partly on commissioned studies of independent analysts and on a new round of consultations with the interested parties.

${ }^{10}$ Manufacturers can terminate contracts if sales targets are not met, but only provided that the manufacturers have not limited supply. Bonuses associated with the sales targets should be based on sales including the sales to other authorized dealers within the manufacturers' network.

11 As before, authorized dealers can sell to intermediaries with a written authorization of endconsumers. However, the intermediaries obtain more possibilities since dealers can no longer be restricted to sell at most $10 \%$ of their sales to one intermediary. This facilitates the operations of intermediaries selling through the internet such as Virgin or OneSwoop in the U.K.

12 Since the block exemption allowed the location clause for a transition period until 2005, the manufacturers who opted for selective distribution could still partly benefit from exclusivity until then.
} 
Second, the qualitative criteria in selective distribution have become stricter to manufacturers. They can still impose minimum training standards and standards on showrooms to their dealers, thereby effectively precluding pure internet companies as authorized dealers. ${ }^{13}$ They can also still control the location of the dealers' primary sales outlets, and may provide more favorable conditions to dealers in objectively defined areas: this gives manufacturers an instrument to ensure geographic coverage in the absence of exclusive territories.

However, manufacturers can no longer force their dealers to provide both sales and after-sales services; hence current dealers may decide to subcontract repair and maintenance to other authorized dealers. The reverse is also true, i.e. authorized repairers cannot be forced to sell new cars. This makes it easier for the previous independent repairers to become authorized repairers, provided that the objective quality criteria are met. Such a change can be significant given that the authorized dealers currently have a market share of $50 \%$ of all repair, and $80 \%$ of repair of cars younger than four years.

Additional efforts are also made to make both the authorized and the remaining independent repairers more independent relative to their car manufacturers. It is stressed that the authorized repairers have the right to buy both original spare parts and spare parts of matching quality from other sources than the manufacturers, except under warrantee works, free servicing contracts or recall operations. ${ }^{14}$ The independent repairers, who do not satisfy the objective quality criteria, should be given access to all technical information, tools and equipment. Furthermore, they have the right to purchase original spare parts or parts of matching quality from the authorized repairers. Once again, the increased independence of authorized and independent repairers can be significant since the spare part producers produce $80 \%$ of all components. Although car manufacturers produced only $20 \%$ of components themselves, they had control over most of the sales through their authorized networks.

\footnotetext{
${ }^{13}$ However, authorized dealers can still sell through the internet if they satisfy the other standards. Furthermore, intermediaries acting on behalf of end-consumers can sell through the internet.

${ }^{14}$ And even if the spare parts are distributed through the manufacturers, the original spare part suppliers can now put their logo next to that of the car manufacturers without loosing the characterization of original spare part.
} 
A third difference with the former distribution system during 1985-2002 relates to the exclusive dealing or non-compete obligations. A manufacturer can no longer impose its dealers to operate multiple brands under separate legal entities and separate management (though it can require that its cars be displayed within brand-specific areas in the showroom). ${ }^{15}$ The manufacturer has the right to require that the dealers buy at least $30 \%$ of its own brand (though the dealers should not necessarily buy these from the manufacturer and they may buy these from other dealers in the network). However, it does not have the right to require that the dealers buy a minimum percentage larger than 30\% (say, require at least 32\%). In practice, this means that dealers are guaranteed to be able to sell at least three different brands (but if all manufacturers impose a $30 \%$ purchase requirement a dealer would effectively be able to sell only three brands). The authorized repairers who are not active in selling new cars have the right to repair an unlimited number of other makes. ${ }^{16}$

The increased possibilities for multi-brand dealerships, together with the abandonment of the requirement to provide both sales and after sales, makes it possible, at least in principle, for supermarkets to enter into the business of selling new cars, of course provided that they satisfy the objective criteria. Supermarkets have frequently shown an interest in entering the car distribution business (even with a limited number of brands). In practice, however, car manufacturers have used the possibilities of quantitative selectivity to avoid distribution through supermarkets. According to a study by Lademann (2001) consumers also show only limited interest in buying cars in supermarkets. Yet this study is based on survey questionnaire data

\footnotetext{
15 "Brands" are defined more narrowly than "manufacturers". For example, Volkswagen and Audi are two different brands, owned by the same manufacturer VW Group.

${ }^{16}$ Manufacturers with market shares under 5\% may resort to the de minimis Notice on agreements of minor importance OJ C 371, 9.12.1997 to argue there is no cumulative foreclosure effect for vertical agreements (except hardcore restrictions). Porsche resorted to this Notice to obtain the possibility of exclusive dealing under the former rules (require separate showrooms and separate sales personnel for competing brands). However, this raises the issue of market definition. As discussed below, Brenkers and Verboven (2006) find that the relevant market should be defined at the segment level or even lower. This makes it questionable that Porsche indeed has a market share of 5\% or lower within the sports segment, and therefore satisfies the conditions of the de minimis Notice.
} 
and not on an empirical analysis of what consumers actually would do if distribution through supermarkets becomes available. ${ }^{17}$

A fourth difference with the former distribution systems is the introduction of market share thresholds above which the block exemption does not apply (so that manufacturers would need to request individual exemptions). These thresholds are close to those in the general block exemption regulation for distribution agreements. Exclusive distribution and exclusive dealing or non-compete obligations (meeting the conditions of the regulation) are safe harbors for manufacturers with market shares below 30\%. Quantitative selective distribution is a safe harbor if market shares are below $40 \%$ (except for spare parts and maintenance where the threshold is $30 \%$ ). Qualitative selective distribution is not subject to market share thresholds.

In sum, the new system is stricter on manufacturers for the following reasons: (1) they can no longer apply both selective and exclusive distribution, (2) fewer qualitative criteria are allowed in selective distribution (no forced tying of sales and after-sales services), (3) the conditions for exclusive dealing (no-compete obligations) are stricter, and (4) the block exemptions only apply for market shares below certain thresholds $(30 \%-40 \%)$.

\subsection{Adoption and enforcement of the block exemption}

We first discuss the adoption of the block exemptions, showing that they had a "straitjacket effect" with all car manufacturers adopting similar vertical restraints. We then discuss enforcement, first of the black clauses and then of the market share thresholds in the most recent 2002 block exemption.

\section{Adoption of the block exemptions}

All car manufacturers have used the benefits from the block exemption to make vertical agreements, though the empirical evidence is limited. Before the new block

\footnotetext{
${ }^{17}$ Some independent supermarkets already exist, e.g. Cardoen in Belgium. These companies obtain most of their car supplies from excess volumes of the car manufacturers, or from imports from nonEEA countries (e.g. Turkey).
} 
exemption regulation of 2002, all dealers active in new car sales were both selective and exclusive. After the reforms in 2002, the manufacturers had to make a choice. However, most manufacturers (except Suzuki) actually adopted selective rather than exclusive distribution. Furthermore, the majority of the authorized dealers (67\%) still provide both sales and after-sales service, compared with $29 \%$ providing after-sales services only, and $4 \%$ providing sales only. Finally, exclusive dealing has been and continues to be quite common practice in many countries, with a brand exclusive dealing rate of $70 \%$, compared to only $57 \%$ in the U.S. It has been less popular in the Scandinavian countries where population density is low, with adoption rates below $50 \% .{ }^{18}$ In sum, one can conclude that the block exemptions had a straitjacket effect, inducing most car manufacturers to adopt the same or similar vertical restraints, especially on the most important ones. This remain the case even after the 2002 reforms, despite the Commission's claimed attempts to get rid of the rigidity and stimulate innovative distribution systems.

\section{Enforcement of black clauses}

To appreciate the European Commission's most important concerns, it is instructive to consider the infringement cases to the black clauses, i.e. agreements that are not exempted regardless of the market share. Table 1 provides an overview of the cases since the first block exemption in 1985. Interestingly, the first case occurred only in 1998, the Volkswagen case. Among other things, the Commission found Volkswagen guilty of the following practices to its Italian dealers: threatening fifty dealers to terminate contracts if they continued to sell to foreigners, with twelve actual terminations; giving lower margins and bonuses to dealers selling to foreign customers; limiting supplies to some of the dealers. The Commission imposed a fine of $€ 102$ million, at that time the largest fine ever for a single firm. There were several subsequent cases, concerning different car manufacturers in several countries of the European Union. All cases relate to either to RPM, which the Commission refers to as "serious" infringements, or to export restrictions, which the Commission refers to as "very serious". This overview shows the Commission's preoccupation with

\footnotetext{
18 The numbers in this paragraph come from Harbour Wade Brown, HWBI Management Briefing $3 / 06 / 7$ and $5 / 05 / 2$, available on the web.
} 
competition issues relating to the realization of the European common market, rather than with more standard competition policy issues.

Table 2. Infringement cases since the first block exemption in 1985

\begin{tabular}{llllll}
\hline Date & Nature of infringement & Country & Company & Duration & Fine \\
1998 & export restrictions & Italy & Volkswagen & $1988-1998$ & $€ 102$ million $^{*}$ \\
2000 & export restrictions & Netherlands & Opel & $1996-2000$ & $€ 43$ million** $^{\star *}$ \\
2001 & RPM (restrict discounts) & Germany & Volkswagen & $1996-1997$ & $€ 31$ million $^{* \star *}$ \\
2001 & export restrictions & Germany & DaimlerChrysler & $1985-2001$ & $€ 72$ million \\
& restrictions on leasers & Germany, Spain & & $1997-2001$ & \\
& RPM (restrict discounts) & Belgium & & $1996-1999$ & \\
2005 & export restrictions & Netherlands & Peugeot & $1997-2003$ & $€ 50$ million \\
\hline
\end{tabular}

Notes:

*: Reduced by Court of First Instance to $€ 90$ million in 2000

**: Reduced by Court of First Instance to $€ 35$ million in 2003

***: Annulled by Court of First Instance in 2003. After appeal the annulation has been reconfirmed in

2006 on the grounds that the Commission had not proved any actual acquiescence by the dealers.

\section{Enforcement issues regarding the 2002 market share thresholds}

According to the most recent 2002 block exemption, the manufacturers are allowed to make vertical agreements, other than the black clauses, only if their market shares do not exceed a certain threshold level. If they have a larger market share, they are not protected by the block exemption and are therefore vulnerable to being sued for breach of Article 81 . As discussed, the market share threshold level is $30 \%$ for most vertical agreements. The only exceptions are quantitative selective distribution (new car sales) for which the market share threshold is $40 \%$, and qualitative selective distribution for which there are no thresholds. To apply these thresholds it therefore becomes critical to define the relevant car market on a sound basis. Should the market be, say, all car sales in the EU? Or should the geographic market be narrower, say at the national level? And should the product market be narrower such that an Opel Corsa is not seen as a close substitute for a BMW? The appropriate way to define an economically sound antitrust market is to conduct the well-known SSNIPtest or "hypothetical monopolist" test. This test takes a group of products as the candidate relevant market, and asks whether a small but significant and non-transitory increase in price (in the range of 5-10\%) would be profitable. If the answer is yes, a relevant market is found. If the answer is no, this means that the hypothetical price 
increase caused too much substitution to other products, so that additional products need to be included in the market and the test should be applied again.

In a recent study, Brenkers and Verboven (2006) apply the economic logic of the SSNIP-test to define the relevant market, and subsequently ask whether the threshold market share conditions are satisfied. They consider five countries (Belgium, France, Germany, Italy and the U.K.), and assume that the geographic markets are the national markets (based on the limited observed cross-border sales despite the large international price differences). They then estimate an empirical demand model with differentiated products. This enables them to measure the extent of substitution between different car models and apply the SSNIP-test. They find that the relevant product markets can usually be defined at the level of the segment (e.g. compact cars), or often even narrower at the level of the origin within the segment (e.g. domestically produced compact cars).

Given these market definitions they then obtain the following findings on the applications of the market share threshold. Most mass producers violate the $40 \%$ market share thresholds in their home countries, and one mass producer (Volkswagen) even violates the market share thresholds in some foreign countries. In contrast, the niche players or Asian manufacturers almost never violate the $40 \%$ threshold conditions. Violations of the $30 \%$ threshold conditions are observed in more cases: by several additional mass producers in foreign countries and by several niche players. To our knowledge, these violations have not prompted the Commission to prohibit vertical agreements with dealers selling new cars. ${ }^{19}$ The reasons for this are unclear to us, but it illustrates that many car manufacturers operate at the limits of the block exemption regulation and may not necessarily remain automatically eligible in the future.

While the market share criteria do not appear to have been strictly enforced, two recent cases show the Commission's commitment to enforce other aspects of the new block exemption regulation of $2002 .^{20}$ In 2006, after complaints from the dealer association, BMW and GM have explicitly recognized the principle of genuine multi-

\footnotetext{
${ }^{19}$ Market share violations have however affected contracts with repairers, since in most cases the manufacturers have a market share in repair over $30 \%$. This implies that typically only qualitative selective distribution is possible, and no restrictions on the total number of repairers are allowed.
} 
brand dealerships. They also accept the principle of qualitative selective distribution, implying that all repair shops who fulfill the qualitative criteria may become members of the manufacturers' authorized network.

\section{Economic analysis}

To prepare its block exemption regulations, the European Commission conducted various external economic studies. These provide an indication of what was motivating the Commission in its various revisions of the block exemption. Most of these studies looked at the effects of the regulation on cross-border trade (including studies on international price differences), further illustrating the European Commission preoccupation with the common market goal. More recently, the European Commission showed a stronger interest in economic analyses of other issues as well (e.g. commissioned studies on intra-brand competition and on the link between sales and after-sales services).

The economic effects of vertical agreements are far less clear-cut than for most horizontal agreements. In the following sections, we provide an overview of the various competition issues emerging from the vertical agreements at issue. After a brief review of possible efficiency benefits we discuss the possible anticompetitive effects. Consistent with the European Commission's emphasis, we first discuss how the distribution system may have limited the possibilities for cross-border trade, thereby creating the possibility of international price discrimination. Next, we discuss how the distribution system may have limited domestic trade or intrabrand competition (between dealers of the same brand), thereby creating a mechanism to soften interbrand competition (between different manufacturers). Finally, we discuss how the distribution system may lie at the basis of foreclosure, of new entrants as well as spare part manufacturers. We spend particular emphasis on the available empirical evidence regarding the possible anti-competitive incentives of the vertical restraints. ${ }^{21}$

\footnotetext{
${ }^{20}$ See BMW IP/06/302 and GM IP/06/303.

${ }^{21}$ To put this evidence in a broader perspective, we refer to Lafontaine and Slade' s (2005) review of the empirical evidence in relation to vertical agreements in general.
} 
We focus our discussion on the effects of the system as it was in place during the period 1985-2002 (and another few years of transition). There is most empirical evidence on that period, and it allows one to evaluate the significance of the reforms after 2002. We hope that our review of economic principles will stimulate a deeper economic analysis of the competition issues in the forthcoming review of the block exemption (to expire in 2010), with a more explicit treatment of both the efficiencies and the various channels through which anticompetitive effects may arise.

\subsection{Efficiencies from distribution agreements}

\subsubsection{Mitigating double marginalization problems}

Since car manufacturers do not charge fixed franchise fees to their dealers, their primary profit source comes from setting wholesale prices above marginal costs (whether for the sales of new cars or for spare parts). Furthermore, the dealers have some geographic market power, because of quantitative selectivity and/or territorial exclusivity. This enables them to add a retail markup to the wholesale price, thereby creating the well-known double marginalization problem: the retail price will be too high from a joint-profit maximizing perspective.

Given that manufacturers do not impose fixed franchise fees and do have some market power because of selectivity and exclusivity, the problem may be overcome through the imposition of several accompanying vertical restraints. RPM may be used since this forces the dealers to set the price desired by the manufacturer, but this is a black clause. Instead, manufacturers may impose the weaker form of a price ceiling as an appropriate response to avoid double marginalization. But if anything, car manufacturers appear to have attempted to impose black clause price floors (through maximum allowed discounts to the recommended retail prices), as illustrated by the above discussed infringement cases. This suggests that the vertical price policies were not motivated by attempts to remove of double marginalization. Nevertheless, quantity fixing or, less restrictively, minimum sales requirements may also resolve the double marginalization problem. This may provide an efficiency rationale for the observed sales targets, promoted through the bonuses or threats to withdraw licenses, which has been common across many car manufacturers. 


\subsubsection{Dealer services incentives and free-riding}

Car manufacturers and their dealers provide both sales and after-sales services, the costs of which can be very high. ${ }^{22}$ Both services include potentially significant costs in investing in infrastructure (showrooms, inventories, technical equipment), training of personnel, and time and quality of service. The empirical evidence on the importance of services is mixed. Marketing research studies by Mittal et al. (1999) and Verhoef and Langerak (2003) suggest that services indeed contribute to brand reputation and brand loyalty. But another study by Punj and Brookes (2002) finds that only a small fraction of the consumers finds the dealer an important factor in the purchase of a new car.

Regardless their quantitative importance, car manufacturers would like to achieve the optimal level of dealer services. This is not guaranteed because of several opposing externalities. First, dealers do not take into account the beneficial impact of their services on the manufacturers' profits. This vertical externality implies too little incentives to provide services. Second, dealers do not take into account the detrimental business-stealing effect of their services on competing dealers' profits. This horizontal externality may create too strong incentives to provide services; see Caillaud en Rey (1986) en Iyer (1998).

Third, the dealer services may contain public good aspects, from which the competing dealers may also benefit. This is especially the case for sales services that involve the provision of information (e.g. through well-established showrooms, demonstration cars, test drives, or personalized communication). Competing dealers may free ride on these services, which reduces their own incentives to invest in services.

Vertical contracts can serve to better align the dealers' incentives to provide services with the car manufacturers' goals. Selective distribution forms a direct way to accomplish this. It enables the manufacturer to impose qualitative service criteria to its dealers, such as the size of the showroom, minimum requirements on equipment and personnel, etc. However, in practice it may be difficult to stipulate everything in a

\footnotetext{
${ }^{22}$ According to the OECD (1997) a typical volume manufacturer was expected to invest up to $€ 6.5$ billion in its distribution network over the coming decade.
} 
selective distribution contract. ${ }^{23}$ As an alternative solution, manufacturers may aim to coordinate the sales services efforts either directly or through their national importers. Several importers indeed provide national advertising campaigns or regional distribution centers with showrooms and the possibility for test drives and other information.

Territorial exclusivity may be a third solution to achieve more optimal sales levels. Similar to RPM, territorial exclusivity creates dealer market power. This removes price competition and induces the dealers to compete more through services; see Telser (1960). It also increases travel costs and therefore increases the probability that consumers buy directly from the servicing dealer instead of going to a competing free-riding dealer. Finally, territorial exclusivity enables the manufacturers to take away the dealers' rents by terminating the agreement in case the service level has not been reached; see Klein and Murphy (1988). A side effect of exclusivity is the creation of double marginalization problems. As we discussed above, in the absence of franchise fees and RPM, this may be resolved through the sales targets and the accompanying bonuses.

According to an influential study of Lexecon (1985) free riding between dealers may especially be a severe problem in an international context. The investments in distribution may differ considerably across countries. Parallel importers then have an incentive to purchase products in the countries where prices are low due low distribution costs, and sell them elsewhere. Arbitrage then takes place on differences distribution costs rather than profits. According to Lexecon (1985) this motivates selective and exclusive distribution in pharmaceuticals as a way to prevent free riding on services across countries. It may also provide an efficiency explanation for the car manufacturers to limit cross-border trade and prevent parallel imports through selective and exclusive distribution.

\footnotetext{
${ }^{23}$ Arrunada et al. (2005) consistently take an incomplete contracting perspective as a way to resolve double-sided moral hazard between car manufacturers and dealers. They apply it to the contracts of 23 Spanish dealerships. They find that contracts typically restrict the dealers' decision rights and give manufacturers most monitoring and enforcement power. Abuse of this power is prevented by the mechanism of the manufacturers' reputational capital.
} 


\subsubsection{Manufacturer investment incentives and free-riding}

The sales and after-sales services may not only be a cause of free-riding between dealers, but also between the manufacturers. For example, the investments in training of sales and technical personnel (whether paid by the dealer or the manufacturer) may not only benefit the own brand but also that of competing brands. To maintain sufficient incentives to invest, an exclusive dealing or non-compete agreement could provide a solution; see Besanko and Perry (1991, 1993).

\subsection{Limited cross-border trade and international price differences}

\subsubsection{Obstacles to cross-border trade}

The combination of selective and exclusive distribution makes it more difficult to engage in cross-border trade (or parallel imports) to take advantage of international price differences. Selectivity eliminates the role of independent resellers, whereas exclusivity makes it impossible for the authorized dealers themselves to actively sell their cars to consumers in other countries. Hence, cross-border trade can only take place if the local authorized dealers sell to one of the following three possible foreign agents: directly to the end-consumers, to intermediaries with a written authorization from end-consumers, or to foreign authorized dealers within the manufacturer's network. Already during the preparations of the first block exemption in 1985, the European Commission had been preoccupied with the concern that the distribution system should form an obstacle to cross-border trade, and should therefore be responsible for the large international price differences. ${ }^{24}$ Consequently, it issued a Notice accompanying the block exemption regulation, which deals with cross-border movements and relative price differences between member states. ${ }^{25}$ One may distinguish between supply side and demand side measures.

\footnotetext{
${ }^{24}$ The Commission has shown a more general interest in promoting cross-border trade in the car market. In addition to its efforts to ensure the distribution system does not limit cross-border trade, it has also taken other measures to ensure that the technical requirements of cars were harmonized. See Goldberg and Verboven (2005) for a more detailed discussion on the Commission's other efforts to promote integration in the car market.

${ }^{25}$ See EC Commission Notice, OJ 1985 C 17/3 of 18.1.1985.
} 
To guarantee a sufficient supply to foreign agents, the Notice required that the authorized dealers should have access to all cars with similar specifications for sale in other countries at a reasonable surcharge (e.g. right-hand-drive cars for U.K. customers). This requirement became known as the "availability clause", and was formally included in the next block exemption regulation of 1995. In practice, however, the manufacturers could limit their supply to their dealers through the system of sales targets. This gave the dealers stronger incentives to sell to local consumers, who may come back for after-sales services. Possibly as a result of this, foreign customers often faced long delivery lags or excessive surcharges. ${ }^{26}$

To protect the demand side, the Notice explicitly stated that end-consumers, as well as their intermediaries, must not face excessive delivery lags, refusals to carry out warrantee works, or lack of cooperation in registering the cars at the border. The Notice also stated that international price differentials should not exceed $12 \%$ for more than one year, or $18 \%$ for a shorter period (after taking into account exchange rate fluctuations and cross-country tax differences). Although the European Commission subsequently began to monitor international price differences, it has never actually enforced the $12-18 \%$ rule: international price differences have varied widely and persistently so, even after controlling for specification differences and even between countries with similar taxes and stable exchange rates. Furthermore, a new Notice in 1991 formally restricted the rights of the intermediaries to ensure that they would not behave like independent resellers. ${ }^{27}$ Finally, as discussed by the U.K. Competition Commission (2000), the foreign authorized dealers also had little incentives to buy cars from the local authorized dealers and sell it to their local consumers: since the manufacturers would typically not count such sales when determining whether the sales targets are met, they would face the risk of not earning bonuses.

\footnotetext{
${ }^{26}$ For example, an anonymous dealer survey by BEUC (1986) revealed a refusal to sell to foreign consumers in $20 \%$ of the cases; excessive delivery lags for right hand drive cars for the U.K. and lower discounts to foreign consumers. These costs obviously add to the high transportation and information costs for consumers seeking to purchase a car abroad.

${ }^{27}$ See EC Commission Notice, OJ 1991 C 329 of 18.12.1991. It formally clarified that intermediaries must not behave like independent resellers through various stipulations: they must avoid carrying a common name; they must not use supermarkets as outlets; and they must quote their prices only as "best estimates". Furthermore, intermediaries and dealers may not establish privileged relationships with each other in form of favourable conditions or sales amounts exceeding $10 \%$ of the dealers' sales.
} 
In sum, the selective and exclusive distribution system as it has been in place up to 2002 has provided only limited incentives to local dealers to sell their cars to foreign agents. At the same time, the role of intermediaries or foreign authorized dealers was restricted so that arbitrage activities had to come directly from end-consumers, most of whom perceive high transaction costs. This conclusion is supported by the evidence: international price differences have been large and persistent, while at the same time the level of parallel imports has been small (at most $2 \%$ and often less); see for example BEUC (1992) and Goldberg and Verboven (2005).

\subsubsection{International price differences}

While the selective and exclusive distribution system may have severely limited cross-border trade, one should not infer that the car manufacturers have deliberately set up the selective and exclusive distribution system to be able to maintain the large and persistent international price differences. It is first necessary to understand the sources of the international price differences. Verboven (1996) and Goldberg and Verboven (2001) address this question. A main conclusion is that differences in local distribution costs are an important explanation for the observed international price differences. ${ }^{28}$ The remaining part is due to differences in markups, i.e. international price discrimination. Markup differences may follow from cross-country differences in conduct (e.g. collusion in the U.K.). They may also follow from intrinsic differences in tastes (e.g. national champions in France and Italy) or from markup adjustment in response to local cost differences. The latter may happen because of exchange rate fluctuations or because of differences in taxes which have to be paid in the country of use. For example, car taxes are very high for consumers in Denmark, and manufacturers have partly absorbed these by lowering their markups. ${ }^{29}$

Given that the distribution system enables firms to engage in international price discrimination, are they better off than in a system where they are constrained to

\footnotetext{
${ }^{28}$ Local costs explain two thirds of observed incomplete exchange rate pass-through, the phenomenon that exporters only partly lower their local prices when the foreign currency appreciates (and vice versa). Markup adjustment explain the remaining part.
} 
charge uniform prices? Under monopoly, the question is generally affirmative, since more options are always better. Under imperfect competition, however, the possibility to price discriminate may reduce profits relative to uniform pricing since they have more instruments to compete; see for example Corts (1998). Brenkers and Verboven (2006) approach the problem empirically; they find that profits would not significantly decrease, and under some conditions may even slightly increase, if the firms would become constrained to charge more uniform prices. This finding needs some qualification, however, since their analysis is limited to a set of countries with similar tax regimes. The profit incentive may become more important when very high tax countries such as Denmark are included. ${ }^{30}$ Subject to this qualification, Brenkers and Verboven's analysis strongly indicates that the possibility to internationally price discriminate is not a main profit motive for the selective and exclusive distribution system, but is only an unintended side effect.

Brenkers and Verboven also ask whether the possibility to price discriminate has affected consumer surplus and total welfare. They find that there may have been large distributional effects, from U.K. consumers to consumers elsewhere in Europe. However, total European consumer surplus is hardly affected. Given the negligible profit effects this implies that the possibility to price discriminate has had no important overall welfare effects. Put differently, the obstacles to cross-border trade may on balance be beneficial if they involve any convincing efficiency benefits (such as resolving the free riding problems in servicing discussed above).

\subsection{Limited domestic trade and softening interbrand competition}

The distribution system may not only have restricted cross-border, but also domestic trade. In principle, territorial exclusivity makes it less likely that consumers buy cars from distant dealers since active selling policies such as targeted advertising are not

\footnotetext{
${ }^{29}$ Intrinsic taste differences and markup adjustment in response to local cost differences are both examples of differences in price elasticities: the first is exogenous, and the second is endogenous due price elasticities being increasing in price.

${ }^{30}$ In various speeches, the Commissioner for Competition Policy Monti, who was in power at the time of the reforms in 2002, has stressed the need for harmonizing taxes. Differing taxes may give manufacturers strong incentives to erect cross-border trade restrictions and charge lower markups in
} 
allowed. Furthermore, selectivity makes it impossible for independent resellers to sell cars elsewhere in the country. To the extent that these vertical restraints restrict domestic trade, there is limited domestic intrabrand competition, i.e. limited competition between dealers of the same brand. According to consumer organizations and policy makers, the available evidence indeed indicates that intrabrand competition has indeed been limited in the car market. The U.K. Competition Commission (2000, 2.117 and 2.322) reports that the extent of out-of territory sales is $39 \%$ of dealer sales, and interprets this as a low number since there are many commuting consumers in the U.K. A long report of the European Commission (2000) has also expressed concerns with limited domestic intrabrand competition. The industry, in contrast, has argued that the distribution system creates sufficient domestic trade opportunities, for example because dealers have been allowed to do non-personalized advertising campaigns outside their territory since 1995. The industry has also interpreted the $39 \%$ out-of territory sales number to be sufficiently high.

Suppose the consumer organizations and policy makers are right, and that selectivity and exclusivity has not just restricted cross-border trade but also domestic intrabrand competition. As has been shown by Rey and Stiglitz (1995), under some circumstances limited intrabrand competition between dealers may also soften interbrand competition between the car manufacturers. The reasoning goes as follows. Limited intrabrand competition creates market power for the dealers. If the car manufacturer is a monopolist, this gives rise to Spengler's (1950) well-known double marginalization problem, i.e. both the manufacturer and the dealer can charge a monopoly markup, giving rise to too high prices, too low demand and hence too low profits to the manufacturer. In contrast, if car manufacturers compete sufficiently intensively with each other, the limited intrabrand competition and the resulting dealer market power may serve as a way to reduce interbrand competition, i.e. soften competition between the car manufacturers and raise their profits.

It is ultimately an empirical question whether the mechanism of reducing intrabrand competition through selective and exclusive distribution to soften interbrand competition is indeed at work. Put differently, would competition between manufacturers intrinsically be sufficiently intense strong to make the mechanism 
profitable? Based on an empirical oligopoly model Brenkers and Verboven (2006) compute the manufacturers' profits under the assumption that the pre-2002 selective and exclusive distribution system indeed eliminated intrabrand competition so that the softening competition mechanism may apply. They then compare this with the profits under the assumption that the distribution system did not successfully eliminate intrabrand competition. They find that profits would actually be higher in the latter case, i.e. when the softening competition mechanism does not apply. Hence, Rey and Stiglitz' conditions that there should be sufficiently strong interbrand competition between manufacturers for the mechanism to work appear not to be satisfied in the European car market. The overall conclusion is that the mechanism of softening interbrand competition through limiting intrabrand competition presumably does not form a profit motive for the selective and exclusive distribution system. It should at most be seen as an unintended side effect that lowers the manufacturers' profits relative to a less restrictive distribution system. The rationale for the selective and exclusive distribution system should therefore be sought elsewhere, for example in efficiencies, or in foreclosure to which we turn in section 3.4.

This discussion assessed whether selective and exclusive distribution indirectly affect interbrand competition through their effects on intrabrand competition. However, other vertical restraints may have a direct effect on interbrand competition. In particular, this may be the case for exclusive dealing or non-compete obligations, which force dealers not to sell competing brands. This raises the search and other information costs to consumers, since they have to visit multiple dealers to learn about the price and quality of competing brands. Hence, exclusive dealing may directly reduce interbrand competition, in contrast with selective and exclusive distribution which may only do so indirectly through the channel of reduced intrabrand competition.

\subsection{Foreclosure}

The vertical agreements in the car market may not only have an impact on competition given the market structure. They may also affect market structure itself,

fluctuations. 
by making the entry conditions of competing manufacturers and of the spare parts manufacturers more difficult. We now discuss to which extent such foreclosure may be a source of concern in the car market.

\subsubsection{Foreclosure of competing manufacturers}

Under exclusive dealing firms force their dealers not to sell competing brands. Such a vertical restraint may create incumbency or first-mover advantages as it increases the costs of new firms trying to enter the market. ${ }^{31}$ Historic evidence suggests that firstmover advantages have indeed been important in the car market. All major current European car manufacturers owe their success to their strength in their home markets: Volkswagen and Opel (taken over by GM) in Germany; Renault, Peugeot and Citroën in France; Fiat, Alfa Romeo and Lancia in Italy; Seat in Spain; Ford, Rover and Vauxhall (also taken over by GM) in the U.K. With the elimination of tariff barriers in 1968 the opportunities to enter in foreign markets improved. However, because of the practice of exclusive dealing these firms had to set up their own distribution networks, a costly and slow process. Even today most manufacturers have considerably stronger positions in their home markets. Similar entry problems have been faced in more recent years by the Asian companies, first by the Japanese and more recently by South-Korean car manufacturers.

According to the Chicago School a dealer would not find it in its own interests to make an exclusive dealing contract with a manufacturer, since this would prevent it from new contracts when potentially more efficient firms would enter the market; see e.g. Bork (1978). However, more recent theories suggest this argument is incomplete; see e.g. Rasmusen et al. (1991) and Segal and Whinston (2000). The starting point of the argument is that there are many potential dealers who cannot coordinate when making contracts with an incumbent car manufacturer. The manufacturer can exploit this lack of coordination and make an exclusive dealing contract with each dealer. Each individual dealer has no incentive to refuse the incumbent's contract and go to a new entrant: this would not affect the entry decision of a new firm who would need to

\footnotetext{
31 As discussed in the previous footnote, exclusive dealing may also reduce interbrand competition, given market structure.
} 
sign contracts with a large group of dealers to be able to profitably enter the market. In sum, while it may not be in the joint interests of a group of dealers to make exclusive dealing contracts, this is the best thing to do from the perspective of each individual dealer given that other dealers are doing the same.

The historic evidence on the car manufacturers' market shares suggests that firstmover advantages have been important. The strong correlations between market shares and dealer networks provide further support. However, there is currently no direct evidence on the role of exclusive dealing in foreclosing new entrants. ${ }^{32}$ At the same time, evidence presented by the European Commission (2000) shows that exclusive dealing contracts have been considerably less popular in the rural areas, such as the Scandinavian countries. This is more consistent with an efficiency explanation: consumers prefer diversity whereas dealers need a minimum scale to be profitable. One may infer that the possible foreclosure incentives of exclusive dealing do not always outweigh their costs (in terms of foregone scale economies).

\subsubsection{Foreclosure of spare part manufacturers}

Until 2002 selective distribution allowed manufacturers to force their dealers to provide both sales and after-sales services. There has been only little evidence on the efficiency reasons for tying both services. Cost-side complementarities appear to be limited. The required technical knowledge for after-sales repair and maintenance services is much more specialized than the knowledge for sales services. Conversely, sales services require specific communication skills that are not needed to the same extent for repair and maintenance. The limited complementary is evident from the specialized personnel for both tasks at most dealers. Demand-side complementarities between sales and after-sales services also seem limited, according to a market research study of Autopolis (2000) commissioned by the European Commission in preparation of the 2002 reforms.

An alternative explanation for the tying of sales and after-sales activities is foreclosure of the spare parts manufacturers. Since the car manufacturers currently

\footnotetext{
${ }^{32}$ Asker (2004) studies exclusive dealing agreements in the beer market of a U.S. metropolitan area, and finds no evidence on foreclosure.
} 
purchase buy about $80 \%$ of their spare parts externally, their core business is building and selling a brand name. By tying sales and after-sales services, the manufacturers may be able to leverage their brand-based market power in the new car market to the after-sales market, where spare parts are needed for both repair and maintenance. This control over the after-sales market is the strongest for repair and maintenance works during the warrantee period, but it extends beyond that if the manufacturers can force the dealers to purchase spare parts from them. In principle, the spare parts manufacturers can invest in a network of independent repairers to capture profits during the post-warrantee period, but this requires equal access to the car manufacturers' technical information, which is often not the case in practice. In sum, by tying sales and after-sales services, the car manufacturers control a dealer network with a strategic advantage over the spare part manufacturers who want to sell to independent repairers. This allows them to obtain a significant fraction of the lucrative after-sales market, which according to some studies amounts to up to $50 \%$ of the car manufacturers' profits.

While the foreclosure of spare part manufacturers reduces the degree of competition in the repair and maintenance market, it may also have beneficial effects. Just as the owner of an essential facility in a network industry, the car manufacturers need to have sufficient incentives to invest in their brand name. When other firms can capture a significant fraction of these benefits, the investment incentives may correspondingly be reduced. We are not aware of solid empirical evidence on the effects of foreclosure of the spare part manufacturers (whether by reducing competition or promoting sufficient investment in brands). This would clearly be important in further investigations.

\section{Concluding remarks}

The recent history of the car distribution system in Europe shows how the European Commission is gradually changing its interpretation of Article 81. The block exemption regulations during the eighties and nineties were preoccupied with the common market concerns, i.e. that the vertical agreements in the car market would create obstacles to cross-border trade and cause large international price differences. While the European car markets are still not fully integrated, progress has been made, 
not only through the policy regarding the distribution system but also through other measures, such as the harmonization of technical standards in the mid-nineties. This progress towards a more integrated European car market may partly explain the Commission's shift in emphasis in the most recent 2002 block exemption. While the Commission still aimed to minimize obstacles to cross-border trade caused by the vertical restraints, it now shows a stronger concern with the core competition policy issues, in particular the promotion of intrabrand competition, i.e. competition between dealers of the same brand.

This shift in emphasis away from the common market concern is a welcome development. Recent research by Brenkers and Verboven (2006) indicated that the European welfare gains from reduced international price differences in an integrated market are limited at best (although there are potentially important distributional effects in favor of the current high price countries). Furthermore, the international price differences should only be interpreted as an unintended side effect and not as a main profit motive for the industry's desire to maintain the vertical restraints.

Nevertheless, considerable progress in economic analysis and policy remains desirable. The 2002 block exemption negotiations stressed the promotion of intrabrand competition and an increased dealer independence from their manufacturers. Yet the economic underpinnings of this new emphasis were rather limited and vague. As noted by Wijckmans, Tuytschaever and Vanderelst (2006), the Commission spent little emphasis on the promotion of interbrand competition, arguing in its Evaluation Report that "there is currently reason to believe that effective interbrand competition exists in the European Union." One interpretation of the Commission's attitude may be that it attempted to promote the consumers' interests (by encouraging intrabrand competition) without affecting too much the manufacturers' interests (by de-emphasizing interbrand competition). Under this interpretation, the (small) dealers' interests may have been hurt most.

In the light of the expiration of the current block exemption regulation in 2010 , further progress in economic policy towards the car distribution system may be realized on several fronts. First, the policy objectives should become more transparent, i.e. the importance that is given to the interests of final consumers, the dealers and the car manufacturers, and the relationship with the common market objective. Second, a deeper economic analysis is required regarding the various 
channels through which the vertical restraints may affect the various parties. Our own economic framework of section 3 stressed that there should be an explicit analysis of both the efficiencies and the anti-competitive effects of the alternative distributional arrangements. Recent empirical evidence suggests that the anti-competitive effects that were emphasized in the European Commission's 2002 reforms (limited crossborder trade and domestic intrabrand competition) appear to be of less concern. This suggests that the stricter policy towards car manufacturers may not have been warranted. However, before concluding that efficiency arguments in favor of vertical restraints dominate, other possible anti-competitive effects of the vertical restraints (e.g. foreclosure of new entry) need more careful empirical analysis. A deeper economic analysis also requires a better motivation of the market threshold criteria and additional transparency on whether and how they are being enforced. Third, a stronger basis should be provided for the stricter policy towards distribution agreements in the car sector than towards distribution agreements in general, for which a parallel block exemption exists. Since the current block exemption regulation for cars will expire simultaneously with the general block exemption in 2010, there is a unique opportunity to consider the possibility of letting car distribution agreements fall under this general block exemption. The argument for a special treatment of car distribution was the fear of the cumulative anticompetitive effects, when all manufacturers in the industry adopt the same or very similar agreements. However, such cumulative effects may also exist in other industries. Furthermore, the current uniformity in distributional agreements (where almost all producers ended up adopting quantitative selectivity) may be partly a consequence of the highly regulatory approach of the 2002 block exemption itself. To make progress on these issues, we hope that our overview will stimulate further economic analysis of car distribution agreements and a careful collection of additional empirical evidence, both by policy makers and academic researchers.

\section{References}

Arrunada, Benito, Luis Garicano and Luis Vazquez, 2005, Completing Contracts Ex Post: How Car Manufacturers Manage Car Dealers, Review of Law and Economics, 1(1), 1-22. 
Asker, John, 2004, Diagnosing Foreclosure due to Exclusive Dealing, mimeo Stern School of Business.

Autopolis, 2000, The Natural Link between Sales and Service: an Investigation for the Competition Directorate General of the European Commission, beschikbaar op http://europa.eu.int/comm/competition/car_sector.

Besanko, B. en Michael Perry, 1991, Resale Price Maintenance and Manufacturer Competition for Exclusive Dealerships, Journal of Industrial Economics, 39, $517-$ 544.

Besanko, B. en Michael Perry, 1993, Equilibrium incentives for exclusive dealing in a differentiated Goods Oligopoly, RAND Journal of Economics, 24, 646-667.

BEUC, 1992, Parallel Market for Cars in the EC, European Bureau of Consumer Unions, 61pp.

Bork, Richard, 1978, The Antitrust Paradox, New York: Basic Books.

Brenkers, Randy en Frank Verboven, 2006, Liberalizing a distribution system: the European Car Market, Journal of the European Economic Association, 4, 216-251.

Brenkers, Randy and Frank Verboven, forthcoming, Market Definition with Differentiated Products: Lessons from the Car Market, in Jay Pil Choi (ed.) Recent Developments in Antitrust: Theory and Evidence, MIT Press.

Caillaud, Bernard, and Patrick Rey, 1986, A Note on Vertical Restraints with the Provision of Distribution Services, mimeo, INSEE and MIT.

Corts, Kenneth S., 1998, Third-Degree Price Discrimination in Oligopoly: All-Out Competition and Strategic Commitment, RAND Journal of Economics, 29 (2), 306323.

European Commission, 2000, Report on the Evaluation of Regulation (EC) No 1475/95 on the Application of Article 85(3) of the Treaty to Certain Categories of Motor Vehicle Distribution and Servicing Agreements, 126p.

Friberg, Richard, 2001, Two monies, two markets? Variability and the option to segment, Journal of International Economics 55, 317-327.

Goldberg, Pinelopi en Frank Verboven, 2001, The Evolution of Price Dispersion in the European Car Market, Review of Economic Studies, 68, 811-848. 
Goldberg, Pinelopi en Frank Verboven, 2005, Market Integration and Convergence to the Law of One Price: Evidence from the European Car Market, Journal of International Economics, 65(1), 49-73.

Lafontaine, F. and M. Slade, 2005, Exclusive contracts and Vertical Restraints: Empirical Evidence and Public Policy, forthcoming.

Lademann, 2001, Customer Preferences for existing and Potential Sales and Servicing Alternatives in Automotive Distribution, study prepared for the European Commission.

Lexecon, 1985, The Economics of Gray-Markets Imports, Chicago, 98pp.

Mathewson, Frank en Ralph Winter, 1984, An Economic Theory of Vertical Restraints, RAND Journal of Economics, 15, 27-38.

McGuire, T. en R. Staelin, 1983, An industry equilibrium analysis of downstream vertical integration, Marketing Science, 2, 161-192.

Mittal, Vittas, Pankaj Kumar en Michael Tsiros, 1999, Attribute-Level Performance, Satisfaction and Behavioral Intentions over Time: a Consumption-System Decision Approach, Journal of Marketing, 63, 88-101.

O.E.C.D., 1997, Market Access Issues in the Automobile Sector, O.E.C.D. Proceedings, 261p.

Punj, Girish en Richard Brookes, 2002, The Influence of Pre-Decisional Constraints on Information Search and Consideration set Formation in New Automobile Purchases, International Journal of Research in Marketing, 19, 383-400.

Rasmusen, Eric, J. Ramseyer and J. Wiley, 1991, Naked Exclusion, American Economic Review, 81, 1137-1145.

Rey, Patrick en Joseph Stiglitz, 1995, The Role of Exclusive Territories in Producers' Competition, RAND Journal of Economics, 26(3), 431-451.

Segal, Igal en Michael Whinston, Naked Exclusion: Comment, American Economic Review, 90, 296-309.

Spengler, J., 1950, Vertical Integration and Anti-Trust Policy, Journal of Political Economy, 58:347-352. 
Telser, L., 1960, Why Should Manufacturers Want Fair Trade?, Journal of Law and Economics, 3, 86-105.

Tirole, Jean, 1989, The Theory of Industrial Organization, Cambridge: The MIT Press.

Verboven, Frank, 1996, International Price Discrimination in the European Car Market, RAND Journal of Economics, 27, 240-268.

Verhoef, Peter en Fred Langerak, 2003, On the Role of Dealers in Brand Loyalty Decisions in the Automotive Industry, mimeo, Erasmus University Rotterdam.

Verouden, Vincent, 2004, Vertical Agreements and Article 81(1) EC: the Evolving Role o Economic Analysis, Antitrust Law Journal, 71, 525-575.

U.K. Competition Commission, 2000, New Cars: a Report on the Supply of New Motor Cars within the U.K, London: HSMO, 411p.

Wijckmans, Frank, Filip Tuytschaever, and Alain Vanderelst, 2006, The Motor Vehicle Distribution Block Exemption, Chapter 11 in: Wijckmans, Frank, Filip Tuytschaever, and Alain Vanderelst, Vertical Agreements in EC Competition Law, Oxford University Press, 464pp. 